\title{
Fasulye Proteini İzolatının Çeşitli Gıda Ürünlerinin Kalite Özelliklerine Etkisi
}

\author{
Elif Terzi ${ }^{1}$, Merve Bilgintürk ${ }^{2}$, Rukiye Gündoğan ${ }^{3}$, Aslı Can Karaça ${ }^{4 *}$ \\ 1 İstanbul Teknik Üniversitesi, Kimya-Metalurji Fakültesi, Gıda Mühendisliği Bölümü, İstanbul, Türkiye, (ORCID: 0000-0001-7324-029X), terzie16@itu.edu.tr \\ 2 İstanbul Teknik Üniversitesi, Kimya-Metalurji Fakültesi, Gıda Mühendisliği Bölümü, İstanbul, Türkiye (ORCID: 0000-0001-8187-9691), bilginturk@itu.edu.tr \\ 3 İstanbul Teknik Üniversitesi, Kimya-Metalurji Fakültesi, Gıda Mühendisliği Bölümü, İstanbul, Türkiye (ORCID: 0000-0001-7509-0467), gundogan17@itu.edu.tr \\ 4* İstanbul Teknik Üniversitesi, Kimya-Metalurji Fakültesi, Gıda Mühendisliği Bölümü, İstanbul, Türkiye (ORCID: 0000-0002-4137-0644), cankaraca@itu.edu.tr
}

(İlk Geliş Tarihi 24 Haziran 2020 ve Kabul Tarihi 11 Ekim 2020)

(DOI: $10.31590 /$ ejosat.757599)

ATIF/REFERENCE: Terzi, E., Bilgintürk, M., Gündoğan, R. \& Can Karaça, A. (2020). Fasulye Proteini İzolatının Çeşitli Gıda Ürünlerinin Kalite Özelliklerine Etkisi. Avrupa Bilim ve Teknoloji Dergisi, (20), 152-161.

Öz

Bu çalışmada, Akkuş şeker fasulyesinden (Phaseolus vulgaris L.) elde edilen protein izolatı kullanımının kek ve bitkisel bazlı köfte gibi ürünlerin kalite özelliklerine etkilerinin incelenmesi amaçlanmış̧ır. Yerel üreticiden temin edilen kuru fasulyeden alkali ekstraksiyon izoelektrik çöktürme yöntemi ile elde edilen protein izolatı 1,3 ve $5 \mathrm{~g} / 100 \mathrm{~g}$ oranlarında tamamen bitkisel bazlı bileşenlerin kullanıldığı kek ve köfte formülasyonlarına ilave edilmiştir. Fasulye proteini izolatı kekte yumurta ve sütü ikame etme amacıyla kullanılırken; köfte uygulamasında tamamen bitkisel bazlı bir formülasyon geliştirmek amacıyla kullanılmıştır. Kek ve köfte numunelerinde besin öğeleri kompozisyonu, fiziksel özellikler, renk ve tekstür özellikleri incelenmiştir. Fasulye proteini izolatı içeren kek numunelerinde hamur özgül ağırlığının kontrol numunesine göre önemli düzeyde yüksek olduğu görülmüsşür. İzolat oranı arttıkça kek yüksekliği önemli düzeyde artmış, pişme kaybı ise kontrole göre azalmıştır. Hem kek kabuğu hem de içi için renk farkı ve esmerleşme indeksi artan izolat oranı ile artmıştır. Fasulye proteini izolatı içeren kek numunelerinin sertlik değeri, kohezyon kapasitesi ve çiğnenebilirlik gibi özelliklerinin kontrol numunesine göre düşük olduğu görülmüştür. İzolat içeren kek numunelerinin duyusal özelliklerinin kontrol numunesinden farklı olduğu saptanmıştır. Bitkisel bazlı köfte numunelerinin pişme özellikleri incelendiğinde, kontrole en yakın olan numunenin $5 \mathrm{~g} / 100 \mathrm{~g}$ izolat içeren köfte numunesi olduğu görülmüsstür. İzolat kullanımı, köftede kontrole göre gözle ayırt edilebilir düzeyde bir renk farkına $\left(\Delta \mathrm{E}^{*}>3\right)$ neden olmuş ve izolat oranı arttıkça hem ürün kabuğu hem de içi için bu renk farkı artmıştır. İzolat içeren ürünlerin sertlik ve kohezyon kapasitesi değerleri kontrole göre düşük bulunurken; $3 \mathrm{~g} / 100 \mathrm{~g} \mathrm{ve} 5 \mathrm{~g} / 100 \mathrm{~g}$ oranında izolat içeren ürünlerin esneklik ve çiğnenebilirlik değerleri kontrolden yüksek bulunmuştur. Son olarak, kontrole göre farklılık testine göre, $3 \mathrm{~g} / 100$ $\mathrm{g}$ ve $5 \mathrm{~g} / 100 \mathrm{~g}$ oranında fasulye proteini izolatı içeren köfte numunelerinin duyusal özelliklerinin kontrol numunesine benzer olduğu saptanmıştır. Elde edilen bulgular, Akkuş şeker fasulyesinin çeşitli ürün formülasyonlarında iyileştirme yapılarak bitkisel protein kaynağı olarak değerlendirilebileceğini göstermiştir.

Anahtar Kelimeler: Fasulye proteini, Baklagil, Ürün uygulaması.

\section{Effect of Bean Protein Isolate on Quality Characteristics of Various Food Products}

\begin{abstract}
The aim of this study was to invesitgate the effect of Akkus sugar bean protein (Phaseolus vulgaris L.) isolate on quality characteristics of cake and plant-based meatballs. Bean protein isolate was produced from local beans using alkali extraction/isoelectric precipitation method and was added to plant-based cake and meatball formulations at 1,3 and $5 \mathrm{~g} / 100 \mathrm{~g}$ levels. Bean protein isolate was used as a replacer for egg and milk in cake formulation. On the other hand, development of a plant-based formulation was aimed in meatball application. Nutritional composition, physical properties, color and textural properties were investigated in cake and meatball samples. Specific gravity of the dough was significantly higher than that of contol in cake samples with isolate. An increase in isolate amount resulted in a significant increase in cake height, whereas it decreased cooking loss compared to control. Colour difference and browing
\end{abstract}

* Sorumlu Yazar: cankaraca@itu.edu.tr 
index increased as the isolate amount increased. Hardness, cohesiveness and chewiness of cake samples with isolate were found to be lower compared to control. Sensory properties of cake samples with isolate were found to be different than the control sample. Plantbased meatballs with $5 \mathrm{~g} / 100 \mathrm{~g}$ isolate was found to be the closest to control in terms of cooking properties. Use of bean protein isolate in meatballs resulted in a colour difference $\left(\Delta \mathrm{E}^{*}>3\right)$ which increased as the amount of isolate increased. Hardness and cohesiveness of meatballs with isolate were found to be lower than that of control. On the other hand, elasticity and chewiness of meatballs with 3 $\mathrm{g} / 100 \mathrm{~g}$ and $5 \mathrm{~g} / 100 \mathrm{~g}$ isolate were found to be higher compared to control. Finally, sensory properties of meatballs with $3 \mathrm{~g} / 100 \mathrm{~g}$ and $5 \mathrm{~g} / 100 \mathrm{~g}$ isolate were found to be similar to control. Our findings indicate that Akkus sugar bean can be utilized as a plant protein source in various food products with some modifications in formulation.

Keywords: Bean protein, Legume, Product application.

\section{Giriş}

Günümüzde tüketici tercihleri, ekonomik nedenler ve sağlık ile ilgili gerekliliklerden dolayı bitkisel kaynaklardan elde edilen proteinlere yönelik gittikçe artan bir talep bulunmaktadır. Çeşitli gıda ürünlerinde hayvansal kaynaklardan elde edilen proteinlerin yerine kullanılabilecek bitkisel kaynaklı protein arayışında baklagiller yüksek protein içerikleri ile ön plana çıkmaktadır (Asgar ve ark., 2010). Asit veya alkali ile ekstraksiyon/izoelektrik çöktürme, tuz ile ekstraksiyon/misel çöktürme, hava ile ayırma ve ultrafiltrasyon gibi çeşitli metotlar kullanılarak bitkisel kaynaklardan protein konsantre ve izolatları üretilmektedir (Boye ve ark., 2010). Baklagillerden elde edilen proteinler su ve yăg tutma, emülsiyon oluşturma, köpük oluşturma ve jelleşme gibi çeşitli fonksiyonel özellikler de gösterdiklerinden; pek çok gıda ürününde bileşen olanak kullanılma potansiyeline sahiptirler (Boye ve ark., 2010).

Kuru fasulye (Phaseolus vulgaris L.), ülkemizde nohut ve mercimekten sonra en fazla tarımı gerçekleştirilen baklagildir (Aydoğan ve ark., 2015; Çulal Kılıç ve ark., 2020; Yolci, 2020). Anadolu'da, iklim şartlarındaki farklılıklar sebebiyle yetiştirilen fasulyelerde zengin çeşitlilik gelişmiştir (Yeken ve ark., 2018). Besin öğeleri açısından zengin bir bileşime sahip olan kuru fasulye, yaklaşık olarak 20-25 g/100 g protein, $60 \mathrm{~g} / 100 \mathrm{~g}$ karbonhidrat, 0,7-1,5 g/100 g oranında yağ içerirken; çeşitlerine göre farklı oranda vitamin, mineral ve fitokimyasallar da içermektedir (Azarpazhooh \& Boye, 2013). Güncel çalışmalarda son yıllarda öne çıkan bileşenlerden olan fasulye proteinleri, albüminler ve globülinler gibi depo proteinlerini ve enzim inhibitörleri ve lektinler gibi bazı metabolik proteinleri kapsamaktadır (Sathe, 2002). Çeşitli yöntemlerle izole edilen fasulye proteinlerinin su ve yağ tutma kapasitesi, köpük oluşturma ve emülsiyon oluşturma gibi fonksiyonel özellikleri çeşitli araştırmacılar tarafından gerçekleştirilen çalışmalarda incelenmiştir (Ferreira ve ark., 2018; He ve ark., 2018; Lafarge ve ark., 2018).

$\mathrm{Bu}$ çalışmada, farklı oranlarda fasulye proteini izolatı kullanımının fırıncılık ve et ürünlerinin çeşitli kalite özelliklerine etkisinin incelenmesi amaçlanmıştır. Tamamen bitkisel kaynaklı hammaddelerin kullanıldığ ürün bileşimleri ile çalışılmış; model ürün olarak firıncılık ürünleri grubundan kek ve et ürünleri grubundan köfte model gidalar olarak seçilmiştir.

\section{Materyal ve Metot}

\subsection{Materyaller}

Çalışmada kullanılan fasulye unu, yerel üreticiden temin edilen Akkuş şeker fasulyesinin (Phaseolus vulgaris L.) laboratuvar ölçekli öğütücüde (A11 Basic, IKA®)-Werke GmbH \& Co., Staufen, Almanya) en yüksek hızda 2 dakika süre ile öğütülmesi ile elde edilmştir. Kek ve köfte üretiminde kullanılan malzemeler (Tablo 1 \& 2) yerel marketlerden temin edilmiştir. Kek karışımının hazırlanmasında; buğday unu (Migros), şeker (Migros), yumurta (Yumurtacım), pastörize süt (Sütaş), kakao (Dr. Oetker), şekerli vanilin (Destan), ayçiçek yă̆ı (Bizim Yağ), kabartma tozu (Piyale) ve karbonat (Anadolu Mutfağı) kullanılmıştır. Köfte karışımının hazırlanmasında ise; buğday unu (Migros), bezelye proteini konsantresi (Veggy), keten tohumu (Hekimce), mısır nişastası (Piyale), galeta unu (Piyale), karbonat (Anadolu Mutfağı), domates salçası (Tamek), biber püresi (Tamek), karabiber, kekik, kimyon (Anadolu Mutfağı), tuz (Billur), ayçiçek yağı (Bizim Yağ) ve kara havuç suyu konsantresi (Aromsa A.Ş) kullanılmıştır. Analizlerde kullanılan kimyasallar analitik saflıkta olup Sigma-Aldrich ve Merck'ten temin edilmiştir.

\subsection{Fasulye Proteini İzolatı Eldesi}

Fasulye proteini izolatı alkali ekstraksiyon - izoelektrik çöktürme metodu ile elde edilmiştir (Ferreira ve ark., 2018). Fasulye taneleri, ögütücü aracılığıyla ince bir un yapısı elde edilene kadar öğütülmüştür. Fasulye unu 1:10 oranında distile su ile karıştırılarak 0,1 N NaOH ile pH 9,0'a ayarlanmış ve bir saat süre ile manyetik karıştırıcı (IKA ${ }^{\circledR}$ RCT Basic, IKA, Staufen, Almanya) ile oda sıcaklığında karıştırılmıştır. Karışım 11000 rpm'de $4^{\circ} \mathrm{C}$ 'de 25 dakika boyunca santrifüj edilmiştir. Süpernetant bir behere alınarak pH'1 1 M HCI ile 4,5'a ayarlanmıştır ve $11000 \mathrm{rpm}, 4^{\circ} \mathrm{C}$ 'de 25 dakika süre ile santrifüj edilmiştir. Dibe çökmüş olan proteinden süpernetant ayrılmış, oluşan çökeltiden suyu uzaklaştırma işlemi, dondurarak kurutucu (Alpha 1-2 LD plus, Martin Christ Gefriertrocknungsanlagen $\mathrm{GmbH}$, Osterode am Harz, Almanya) yardımıyla $-50^{\circ} \mathrm{C}$ 'de 18 saat süreyle gerçekleştirilmiştir. Elde edilen toz formdaki protein izolatı sıkıca kapalı bir kap içerisinde $4^{\circ} \mathrm{C}$ 'de depolanmıştır.

\subsection{Kek ve Köfte Numunelerinin Bileşimi ve Hazırlanması}

Kek numunelerinin hazırlanmasında Jarpa-Parra ve ark.(2017)'nın çalışmasında kullanılan formülasyondan yararlanılmış; yumurta ve süt içeren kontrol örneği ve 1,3 ve 5 $\mathrm{g} / 100 \mathrm{~g}$ oranlarında fasulye proteini izolatı içeren örnekler olmak üzere toplam dört farklı örnek hazırlanmıştır (Tablo 1). Fasulye proteini izolatı kekte yumurta ve sütü ikame etme amaciyla kullanılmıştır. Tamamen bitkisel bazlı kek formülasyonu geliştirilmesi amaçlanmıştır. Kontrol örneği hazırlanırken öncelikle yumurta ve şeker elektrikli karıştırıcı yardımı ile en yüksek devirde 5 dakika boyunca çırpılmıştır. Fasulye proteini içeren numunelerde ise öncelikle fasulye proteini izolatı oda sıcaklığındaki içme suyu içerisinde çözdürülmüşsür. İzolat çözeltisi, şeker ilave edilerek elektrikli karıştırıcı yardımı ile en yüksek devirde 5 dakika boyunca köpük oluşumu gözlenene dek çırpılmıştır. Ardından sıvı yăg ilave edilmiş ve 2 dakika daha çırpma işlemi sürdürülmüştür. Son olarak toz bileşenler (buğday 
unu, kakao, kabartma tozu, karbonat, şekerli vanilin) ilave edilmiş ve karışım homojen hale getirildikten sonra karıştırma işlemi sonlandırılmıştır. Hazırlanan karışım, karton kek kalıplarına aktarılarak, $180^{\circ} \mathrm{C}$ 'de önceden 1 sıtılmış elektrikli fırında 40 dakika süreyle pişirilmiştir.

Tablo 1. Kek Numunelerinin Hazırlanmasında Kullanılan Formülasyonlar

\begin{tabular}{lcccc}
\hline \multicolumn{1}{c}{$\begin{array}{c}\text { Bileşen } \\
(\mathbf{g} / \mathbf{1 0 0} \mathbf{g})\end{array}$} & Kontrol & $\mathbf{1} \mathbf{g} / \mathbf{1 0 0} \mathbf{g}$ İzolat & $\mathbf{3} \mathbf{g} / \mathbf{1 0 0} \mathbf{g}$ İzolat & $\mathbf{5} \mathbf{g} / \mathbf{1 0 0} \mathbf{g}$ İzolat \\
\hline Buğday unu & 18,50 & 18,50 & 18,50 & 18,50 \\
Şeker & 23,00 & 23,00 & 23,00 & 23,00 \\
Fasulye Proteini & - & 1,00 & 3,00 & 5,00 \\
izolatı & & & & \\
Su & - & 39,00 & 37,00 & 35,00 \\
Yumurta & 13,00 & - & - & - \\
Süt & 27,00 & - & - & - \\
Kakao & 2,75 & 2,75 & 2,75 & 2,75 \\
Vanilin & 1,35 & 1,35 & 1,35 & 1,35 \\
Ayçiçek yağı & 14,00 & 14,00 & 14,00 & 14,00 \\
Kabartma tozu & 0,20 & 0,20 & 0,20 & 0,20 \\
Karbonat & 0,20 & 0,20 & 0,20 & 0,20 \\
\hline
\end{tabular}

Bitkisel bazlı köfte numunelerinin hazırlanmasında buğday unu ve bezelye proteini içeren kontrol örneği ile 1,3 ve $5 \mathrm{~g} / 100 \mathrm{~g}$ oranlarında fasulye proteini izolatı içeren örnekler olmak üzere dört farklı örnek hazırlanmıştır (Tablo 2). Öncelikle keten tohumunun üzerine su ilave edilerek jel formu alana kadar $+4^{\circ} \mathrm{C}$ 'de 20 dakika süreyle bekletilmiştir. Ardından fasulye proteini izolatı su içerisinde çözdürülerek izolat çözeltileri elde edilmiştir. Havuç, soğan, sarımsak gibi bileşenler rende yardımı ile küçük parçalara ayrılmıştır. İzolat çözeltisi, keten tohumu, toz bileşenler (fasulye unu, mısır nişastası, galeta unu, kekik, kimyon, karabiber, karbonat, tuz) ve diğer bileşenler (havuç, soğan, sarımsak, biber püresi, domates salçası) bir kap içerisine eklenerek homojen hale gelene kadar karıştırılmıştır. Ardından sıvı yağ ilave edilmiştir. En son aşamada kırmızı et benzeri renk elde edilebilmesi için kara havuç suyu konsantresi ilave edilmiş ve karıştırma işlemi tekrarlanmıştır. Elde edilen karışımdan; $6 \mathrm{~cm}$ çapında ve $1 \mathrm{~cm}$ kalınlığında köfteler hazırlanmış ve önceden 1sıtılmış kızgın ayçiçek yağında, her bir yüzü 2,5 dakika olacak şekilde toplam 5 dakika süreyle orta ateşte kızartılmıştır.

\subsection{Kalite Özelliklerinin Belirlenmesi}

\subsubsection{Besin Öğeleri Kompozisyonu}

Fasulye unu, fasulye proteini izolat1, kek ve köfte numunelerinin besin öğeleri kompozisyonu AOAC resmi metotları esas alınarak belirlenmiştir (AOAC, 1990).

\subsubsection{Kek Numunelerine Uygulanan Analizler}

Kek hamurunun özgül ağırlığı Paraskevopoulou ve ark. (2015) tarafindan tanımlanan metot esas alınarak; kek hamurunun ağırlığının, eşit hacimdeki saf suyun ağırlığına bölünmesi ile hesaplanmıştır. Kek verimi ve pişme kaybı Dizlek \& Altan (2013) tarafindan tanımlanan metoda göre belirlenmiştir. Kek yüksekliği Jarpa-Parra ve ark. (2017) tarafindan belirtildiği gibi, kek numuneleri ortadan dikey olarak kesilerek ve en yüksek noktanın yüksekliği ölçülerek tayin edilmiştir. Tekstür Profili Analizi (TPA) ise, pişirme işleminin üzerinden yaklaşık 3 saat geçtikten sonra keklere Guadarrama-Lezama ve ark. (2016) tarafindan tanımlanan metotta bazı değişiklikler yapılarak, Lloyd TAPlus tekstür analiz cihazı (Lloyd, İngiltere) kullanılarak gerçekleştirilmiştir. Numuneler analiz için $20 \mathrm{~mm}$ x $20 \mathrm{~mm}$ x 20 mm boyutlarında küpler halinde kesilmiştir. Analizde $25 \mathrm{~mm}$ çaplı silindirik aparat kullanılmış, test hızı $1 \mathrm{~mm} / \mathrm{s}$, gerilme $\% 40$ ve trigger yükü $10 \mathrm{~g}$ olarak ayarlanmıştır. TPA ile kek numunelerinde sertlik, yapışkanlık, esneklik, çiğnenebilirdik ve katılık parametreleri tayin edilmiştir. Kek numunelerinin renk ölçümü ve kontrol numunesi ile diğer numuneler arasındaki toplam renk farkı $\left(\Delta \mathrm{E}^{*}\right)$ hesabı, Jarpa-Parra ve ark. (2017) tarafindan tanımlanan metoda göre, Konica Minolta Chroma Meter CR-400 renk ölçüm cihazı (Konica Minolta, Japonya) kullanılarak gerçekleştirilmiştir. Ölçüm sonuçları CIE (L*, a*, b*) sistemi ile ifade edilmiştir. Esmerleşme indeksi ise Shaabani ve ark. (2018) tarafindan tanımlanan metoda göre aşağıdaki formül kullanılarak hesaplanmıştır.

$$
\Delta \mathrm{E}^{*}=\left[\left(\Delta \mathrm{L}^{*}\right)^{2}+\left(\Delta \mathrm{a}^{*}\right)^{2}+\left(\Delta \mathrm{b}^{*}\right)^{2}\right]^{\frac{1}{2}}
$$


Tablo 2. Bitkisel Bazlı Köfte Numunelerinin Hazırlanmasında Kullanılan Formülasyonlar

\begin{tabular}{lcccc}
\hline \multicolumn{1}{c}{ Bileşen (g/100 g) } & Kontrol & $\begin{array}{c}\mathbf{1 ~ g / 1 0 0 ~ g} \\
\text { Izolat }\end{array}$ & $\begin{array}{c}\mathbf{3 ~ g / 1 0 0 ~ g} \\
\text { Izolat }\end{array}$ & $\begin{array}{c}\mathbf{5} \mathbf{g} / \mathbf{1 0 0} \mathbf{~ g} \\
\text { Izolat }\end{array}$ \\
\hline Buğday unu & 19,80 & - & - & - \\
Fasulye unu & - & 19,80 & 19,80 & 19,80 \\
Fasulye proteini izolatı & - & 1,00 & 3,00 & 5,00 \\
Bezelye proteini konsantresi & 6,80 & - & - & - \\
Su & 26,57 & 32,35 & 30,35 & 28,35 \\
Keten tohumu & 3,30 & 3,50 & 3,50 & 3,50 \\
Misir nişastas1 & 3,30 & 3,30 & 3,30 & 3,30 \\
Galeta unu & 3,30 & 3,30 & 3,30 & 3,30 \\
Karbonat & 0,09 & 0,09 & 0,09 & 0,09 \\
Havuç & 9,90 & 9,90 & 9,90 & 9,90 \\
Soğan & 10,60 & 10,6 & 10,60 & 10,60 \\
Sarımsak & 0,72 & 0,72 & 0,72 & 0,72 \\
Domates salçası & 1,98 & 1,98 & 1,98 & 1,98 \\
Biber püresi & 1,98 & 1,98 & 1,98 & 1,98 \\
Karabiber & 0,20 & 0,20 & 0,20 & 0,20 \\
Kekik & 0,09 & 0,09 & 0,09 & 0,09 \\
Kimyon & 0,17 & 0,17 & 0,17 & 0,17 \\
Tuz & 1,02 & 1,02 & 1,02 & 1,02 \\
Ayçiçek yağ1 & 10,18 & 10,18 & 10,18 & 10,18 \\
Kara havuç suyu konsantresi & 0,15 & 0,15 & 0,15 & 0,15 \\
\hline
\end{tabular}

\subsubsection{Köfte Numunelerine Uygulanan Analizler}

Köfte numunelerinde pişme verimi, pişme kaybı ve nem tutma yüzdeleri Kumar \& Sharma (2004) tarafından tanımlanan metoda göre gerçekleştirilmiştir. Pişme özelliklerinin belirlenebilmesi için öncelikle köftelerin kızartmadan önceki ağırlığı, kalınlığı ve çapı ölçülmüştür. Aynı ölçümler köfteler kızartıldıktan sonra tekrar edilmiştir. Köfte numunelerinin pişme verimi yüzdesi; pişmiş köfte ağırlığının çiğ ağırlığa oranının 100 ile çarpılması ile hesaplanmıştır. Pişme kaybı yüzdesi ise; pişmiş ağırlık ile çiğ ağırlık arasındaki farkın, çiğ ağırlığa bölünerek 100 ile çarpılması ile elde edilmiştir. Pişirme işleminin üzerinden yaklaşık 2 saat geçtikten sonra köftelerin tekstür profili analizi ise Turp (2016) tarafindan tanımlanan metotta bazı değişiklikler yapılarak, Lloyd TAPlus tekstür analiz cihazı ile gerçekleştirilmiştir. Numuneler analiz için $15 \mathrm{~mm}$ x $15 \mathrm{~mm}$ x 15 mm boyutlarında küpler halinde kesilmiştir. Analizde $25 \mathrm{~mm}$ çaplı silindirik aparat kullanılmıştır. Test hızı $5 \mathrm{~mm} / \mathrm{s}$, gerilme $\% 40$, trigger yükü $5 \mathrm{~g}$ olarak ayarlanmıştır. Numuneler aparatın her inişi arasında 5 saniye ve uzaklık $10 \mathrm{~mm}$ olacak şekilde iki kez sıkıştırılmıştır. Tekstür profili analizi ile köfte numunelerinde sertlik, esneklik, çiğnenebilirdik ve katılık tayin edilmiştir. Köftelerde renk ölçümü kızartma işleminde 30 dakika sonra Serdaroğlu ve ark. (2005) tarafından tanımlanan metoda göre Konica Minolta Chroma Meter CR-400 renk ölçüm cihazı (Konica Minolta, Japonya) ile gerçekleştirilmiştir..

\subsubsection{Duyusal Analiz}

Kek ve köfte numunelerine uygulanan duyusal analiz, 20-56 yaşları arasında, 20 eğitimsiz panelist (12 kadın, 8 erkek) ile gerçekleştirilmiştir. Panelistlere Meilgaard ve ark. (2007) tarafından tanımlandığı şekilde, kontrole göre farklılık testi uygulanmıştır. Her örnek; panelistlerin aralarında ilişki kuramayacağ1 şekilde, rastgele üç haneli kod ile etiketlenmiştir. Örnekler; kontrol ile birlikte ikili gruplar halinde panelistlere sunulmuş ve kontrol ile bir diğer numunenin arasındaki farklılığı 0 ile 10 arasında puanlamaları istenmiştir. Bu puanlama 0; tamamen aynı, 10; tamamen farklı olacak şekilde gerçekleştirilmiştir.

\section{5. İstatistiksel Analiz}

Tüm ölçümler üç tekrarlı olarak gerçekleştirilmiştir. İstatistiksel analiz için SPSS (Versiyon 15, IBM, ABD) programı kullanılmıştır. Besin öğeleri kompozisyonu ve ürün kalite özellikleri arasındaki farklılıklar Tek-Yollu ANOVA ve Scheffe Testi ile; duyusal analiz sonuçları arasındaki farklılıklar ise Dunnett Çoklu Karşılaştırma Testi ile $p<0,05$ önem düzeyinde belirlenmiştir.

\section{Araştırma Sonuçları ve Tartışma}

\subsection{Besin Öğeleri Kompozisyonu}

Çalışmada kullanılan fasulye ununun ve bu undan alkali ekstraksiyon/izoelektrik çöktürme metodu ile elde edilen fasülye proteini izolatının besin öğeleri kompozisyonu Tablo 3 'te gösterilmiştir. Sánchez-Arteaga ve ark. (2014) tarafından yapılan çalışmada 6 farklı türe ait fasulye unlarının kompozisyonu analiz edilmiştir. $\mathrm{Bu}$ çalışmaya göre fasulye unlarının protein oranları 20,0 ila 22,6 g/100 g arasında, yağ oranları 0,9 ila 1,8 g/100 g arasında, kül oranları 4,2 ila 7,2 g/100 g arasında, nem oranları ise 6,4 ila $8,9 \mathrm{~g} / 100 \mathrm{~g}$ arasında bulunmuştur. Alves ve ark. (2019) tarafından gerçekleştirilen farklı bir çalışmada ise iki farklı fasulye türü incelenmiş ve kabukları ayrılmamış fasulyelerden elde edilen unların protein içeriği $21,2 \mathrm{~g} / 100 \mathrm{~g}$, yağ içeriği 1,4 $\mathrm{g} / 100 \mathrm{~g}$, kül içeriği 5,2 g/100 g, nem içeriği ise $11,8 \mathrm{~g} / 100 \mathrm{~g}$ olarak 
rapor edilmiştir. $\mathrm{Bu}$ bağlamda çalışmamızda kullanılan fasulye ununun protein içeriği $(21,2 \mathrm{~g} / 100 \mathrm{~g})$ literatürdeki çalışmalarda rapor edilen değerlere benzerlik göstermektedir. Toplam yağ, kül ve nem değerleri arasında görülen farklılıkların ise fasulye türü, yetiştirildiği coğrafi bölge ve iklim koşulları gibi farklılıklardan etkilenebileceği bildirilmiştir.

Çalışmamızda fasulye unundan alkali ekstraksiyonizoelektrik çöktürme metodu ile elde edilen fasülye proteini izolatının protein içeriği 85,5 $\pm 1,2 \mathrm{~g} / 100 \mathrm{~g}$ olarak bulunmuştur (Tablo 3). Wani ve ark. (2015) tarafından 5 farklı fasulye türünden alkali ekstraksiyon-izoelektrik çöktürme metodu ile elde edilen protein izolatlarının protein içeriği 77,0 ila 84,0 g/100 g arasında bulunmuştur. Bir başka çalışma ise Rui ve ark. (2011) tarafından 9 farklı fasulye türü ile gerçekleştirilmiştir. Bu çalışmada yağı uzaklaştırılmış fasulye unundan elde edilen izolatların protein içerikleri 84,0 ila 89,3 g/100 g arasında bulunmuştur. Bitkisel kaynaklardan elde edilen protein izolatlarında protein ekstraksiyon verimi çalışılan hammadde türü, ekstraksiyonda kullanılan yöntem, un:solvent oranı, sicaklık, pH, süre gibi çalışma koşullarından etkilenmekle beraber; çalışmamızda elde edilen fasulye proteini izolatının protein oranının literatürdeki çalışmalarda rapor edilen değerlere benzer olduğu görülmüştür.

Tablo 3. Fasulye Unu ve Fasulye Proteini İzolatının Besin Öğeleri Kompozisyonu ${ }^{1}$

\begin{tabular}{|c|c|c|c|c|c|}
\hline & $\begin{array}{c}\text { Nem } \\
(\mathrm{g} / 100 \mathrm{~g})\end{array}$ & $\begin{array}{l}\text { Protein } \\
(\mathrm{g} / 100 \mathrm{~g})\end{array}$ & $\begin{array}{c}\text { Yă } \\
(\mathrm{g} / 100 \mathrm{~g})\end{array}$ & $\begin{array}{c}\text { Karbonhidrat }^{2} \\
(\mathrm{~g} / 100 \mathrm{~g})\end{array}$ & $\begin{array}{c}\text { Kül } \\
(\mathrm{g} / 100 \mathrm{~g})\end{array}$ \\
\hline Fasulye unu & $13,6 \pm 0,1$ & $21,2 \pm 0,2$ & $0,8 \pm 0,0$ & 60,7 & $3,7 \pm 0,1$ \\
\hline Fasulye proteini izolatı & $5.1 \pm 0.4$ & $85,5 \pm 1,2$ & $0.8 \pm 0.1$ & 5,5 & $3.1 \pm 0.1$ \\
\hline
\end{tabular}

${ }^{1}$ Sonuçlar üç ölçümün ortalaması \pm standart sapma şeklinde veilmiștir.

${ }^{2}$ Karbonhidrat içeriği, protein, nem, yağ ve kül içerikleri belirlendikten sonra 100 g'dan çıkarılarak hesaplanmıştır.

\subsection{Fasulye Proteini İzolatının Kek Numunelerinin Kalite Özelliklerine Etkisi}

Kek numunelerinin besin öğeleri kompozisyonu Tablo 4'te gösterilmiştir. Beklendiği üzere, formülasyona eklenen fasulye proteini izolatı oranı arttıkça kek numunelerinin protein içeriği de artmıştır. Yumurta ve süt içeren kontrol numunesinin nem içeriğinin fasulye proteini izolatı içeren numunelerin nem içeriğinden yüksek olduğu görülmüştür $(p<0,05)$. Çalışmamıza benzer olarak, Lin ve ark. (2017) tarafından yapılan çalışmada yumurta yerine soya protein izolatı kullanılmış ve izolat içeren numunenin nem içeriğinin kontrol numunesine göre düşük olduğu görülmüş ve bu durumun baklagil proteinlerinin su tutma kapasitesinin yumurta proteinlerinin su tutma kapasitesinden düşük olmasından kaynaklanabileceği bildirilmiştir. Fasulye proteini izolatı içeren numunelerde izolat oranı arttıkça nem içeriğinin de arttığı görülmüştür. Yumurta ve süt içeren kontrol numunesinin yağ içeriğinin fasulye proteini izolatı içeren numunelerin yağ içeriğinden yüksek olduğu görülmüştür $(p<0,05)$. Kontrol numunesinin yağ içeriği $(15,2 \mathrm{~g} / 100 \mathrm{~g})$ ile fasulye proteini izolatı içeren numunelerin ortalama yağ içeriği $(14.8 \mathrm{~g} / 100 \mathrm{~g})$ arasındaki fark ürünün toplam kalori değerinde önemli bir değiş̧ikliğe neden olacak düzeyde değildir. Öte yandan; yağ içeriğindeki farkın ürünün ağız hissi ve çiğnenebilirlik gibi duyusal özelliklerinde fark yaratabileceği göz önünde bulundurulması gereken bir faktördür.

Tablo 4. Kek Numunelerinin Besin Öğeleri Kompozisyonu ${ }^{l}$

\begin{tabular}{|c|c|c|c|c|c|}
\hline & $\begin{array}{c}\text { Nem } \\
(\mathrm{g} / \mathbf{1 0 0} \mathrm{g})\end{array}$ & $\begin{array}{l}\text { Protein } \\
(g / 100 \text { g) }\end{array}$ & $\begin{array}{c}\text { Yağ } \\
(\mathrm{g} / 100 \mathrm{~g})\end{array}$ & $\begin{array}{c}\text { Karbonhidrat }^{2} \\
\text { (g/100 g) }\end{array}$ & $\begin{array}{c}\text { Kül } \\
(\mathrm{g} / 100 \mathrm{~g})\end{array}$ \\
\hline Kontrol & $32,5 \pm 0,0^{\mathrm{a}}$ & $4,3 \pm 0,0^{c}$ & $15,2 \pm 0,1^{\mathrm{a}}$ & 47,0 & $1,0 \pm 0,0^{\mathrm{a}}$ \\
\hline $1 \mathrm{~g} / 100 \mathrm{~g}$ fasulye proteini izolatı içeren kek & $27,2 \pm 0,2^{\mathrm{d}}$ & $4,1 \pm 0,1^{\mathrm{c}}$ & $14,7 \pm 0,0^{\mathrm{b}}$ & 53,2 & $0,8 \pm 0,0^{\mathrm{b}}$ \\
\hline $3 \mathrm{~g} / 100 \mathrm{~g}$ fasulye proteini izolatı içeren kek & $28,6 \pm 0,2^{c}$ & $5,6 \pm 0,1^{\mathrm{b}}$ & $14,9 \pm 0,1^{\mathrm{b}}$ & 50,0 & $0,9 \pm 0,1^{\mathrm{ab}}$ \\
\hline $5 \mathrm{~g} / 100 \mathrm{~g}$ fasulye proteini izolatı içeren kek & $29,6 \pm 0,1^{b}$ & $7,2 \pm 0,1^{\mathrm{a}}$ & $14,8 \pm 0,0^{\mathrm{b}}$ & 47,5 & $0,9 \pm 0,1^{\mathrm{ab}}$ \\
\hline
\end{tabular}

${ }^{1}$ Sonuçlar üç ölçümün ortalaması \pm standart sapma şeklinde rapor edilmiștir. Aynı sütun içerisinde farklı harflerle gösterilen değerler birbirlerinden istatistiksel olarak önemli düzeyde farklıdır $(p<0,05)$.

${ }^{2}$ Karbonhidrat içeriği, protein, nem, yağ ve kül içerikleri belirlendikten sonra 100 g'dan çıkarılarak hesaplanmıştır.

Kek numunelerinin pişme ile ilgili fiziksel özellikleri Tablo 5'te gösterilmiştir. Fasulye proteini izolatı içeren kek numunelerinin hamur özgül ağırlığının kontrol numunesine göre yüksek olduğu görülmüştür $(p<0,05)$. Çalışmamıza benzer sonuçlar soya proteini izolatı (Lin ve ark., 2017) ve mercimek proteini izolatı (Jarpa-Parra ve ark., 2017) içeren kekler için de rapor edilmiştir. Özgül ağırlıktaki artışın hamura daha az hava girişinin göstergesi olduğu bildirilmiş ve bu durum baklagil kaynaklı proteinlerin köpük oluşturma kapasitesinin iyi olmasına karşın yumurta proteinlerinden düşük olması ile açıklanmıştır. Formülasyonda kullanılan proteinin elde edildiği kaynak etkili bir parametre olmakla birlikte; ürünün nem içeriğinde gözlenen farklar da hamur özgül ağırlığına etki edebilmektedir. Fasulye proteini izolatı içeren numunelerde izolat oranı arttıç̧a kek yüksekliğinin ve kek veriminin arttığı, pişme kaybının ise azaldı̆̆ görülmüştür $(p<0,05)$. Kek verimi hamurdan uzaklaşan su ile 
azaldığından, kek veriminin artmasına sebep olarak artan protein oranı ile su tutma kapasitesinin artması gösterilmektedir. Kek yüksekliğindeki iyileşme ise, hamurun viskoelastik özelliklerinin izolat ilavesi ile gelişmesi ve çırpma sırasında daha fazla hava tutması ile ilişkilendirilmektedir (Shevkani \& Singh, 2014).

Tablo 5. Kek Numunelerinin Fiziksel Özellikleri ${ }^{1}$

\begin{tabular}{|c|c|c|c|c|}
\hline & $\begin{array}{c}\text { Hamur Özgül } \\
\text { Ağırlığı }\end{array}$ & $\begin{array}{c}\text { Kek Verimi } \\
(\%)\end{array}$ & $\begin{array}{c}\text { Pişme Kaybı } \\
(\%)\end{array}$ & $\begin{array}{c}\text { Yükseklik } \\
(\mathbf{m m})\end{array}$ \\
\hline Kontrol & $1,15 \pm 0,00^{\mathrm{c}}$ & $90,7 \pm 0,1^{\mathrm{a}}$ & $9,3 \pm 0,1^{\mathrm{c}}$ & $25,3 \pm 0,6^{b}$ \\
\hline $1 \mathrm{~g} / 100 \mathrm{~g}$ fasulye proteini izolatı içeren kek & $1,17 \pm 0,00^{\mathrm{b}}$ & $88,9 \pm 0,0^{c}$ & $11,1 \pm 0,0^{\mathrm{a}}$ & $21,0 \pm 1,0^{c}$ \\
\hline $3 \mathrm{~g} / 100 \mathrm{~g}$ fasulye proteini izolatı içeren kek & $1,19 \pm 0,00^{\mathrm{a}}$ & $90,1 \pm 0,0^{\mathrm{b}}$ & $9,9 \pm 0,0^{b}$ & $23,7 \pm 1,2^{\mathrm{b}}$ \\
\hline $5 \mathrm{~g} / 100 \mathrm{~g}$ fasulye proteini izolatı içeren kek & $1,17 \pm 0,01^{b}$ & $90,2 \pm 0,2^{b}$ & $9,8 \pm 0,2^{\mathrm{b}}$ & $28,3 \pm 0,6^{\mathrm{a}}$ \\
\hline
\end{tabular}

Kek numunelerinin kabuk ve iç renklerine ait parametreler ve esmerleşme indeksi değerleri Tablo 6'da gösterilmiştir. Ölçümde kullanılan CIE renk parametreleri $L^{*}\left(L^{*}=0\right.$; siyah ve $L^{*}=100$; beyaz), $a^{*}\left(-a^{*}\right.$; yeşillik ve $+a^{*}$; kırmızılık) ve $b^{*}\left(-b^{*}\right.$; mavilik ve $+b^{*}$; sarılık) değerleridir (Baixauli ve ark., 2008). Fasulye proteini izolatı içeren numunelerde izolat oranı arttıkça kabukta $L^{*}$ değerlerinin azaldığı $(p<0,05)$; dolayısıyla siyaha yakınlığın arttığı görülmüștür. Kek numunelerinin kabuk ve iç renklerine ait $a^{*}$ ve $b^{*}$ parametreleri ise değişkenlik göstermiştir. Baklagil kaynaklı protein ilaveli keklerde kabuk renginin Maillard reaksiyonundan ve pişirme sırasında gerçekleşen karamelizasyondan etkilendiği, iç renginin ise formülasyonda kullanılan hammaddelerden etkilendiği bildirilmiştir (Majzoobi ve ark., 2013; Lin ve ark., 2017).

\section{Tablo 6. Kek Numunelerinin Renk Parametreleri ${ }^{1}$}

\begin{tabular}{|c|c|c|c|c|c|}
\hline & $L^{*}$ & $a^{*}$ & $b^{*}$ & $\Delta E^{*}$ & $\begin{array}{c}\text { Esmerleşme } \\
\text { indeksi }\end{array}$ \\
\hline \multicolumn{6}{|l|}{ Kontrol } \\
\hline Kabuk & $28,71 \pm 0,23^{\mathrm{a}}$ & $9,13 \pm 0,17^{\mathrm{a}}$ & $9,60 \pm 0,26^{\mathrm{a}}$ & - & $63,12^{\mathrm{a}}$ \\
\hline İç & $20,26 \pm 0,73^{\mathrm{d}}$ & $9,66 \pm 0,29^{d}$ & $10,65 \pm 0,41^{\mathrm{d}}$ & - & $106,28^{\mathrm{d}}$ \\
\hline \multicolumn{6}{|c|}{$1 \mathrm{~g} / 100 \mathrm{~g}$ fasulye proteini izolatı içeren kek } \\
\hline Kabuk & $22,81 \pm 0,36^{\mathrm{b}}$ & $4,35 \pm 0,29^{b}$ & $2,85 \pm 0,01^{\mathrm{c}}$ & $10,17^{\mathrm{b}}$ & $26,73^{\mathrm{b}}$ \\
\hline İç & $19,58 \pm 0,37^{\mathrm{df}}$ & $10,33 \pm 0,06^{\mathrm{e}}$ & $10,76 \pm 0,37^{\mathrm{d}}$ & $1,04^{\mathrm{d}}$ & $114,28^{\mathrm{d}}$ \\
\hline \multicolumn{6}{|c|}{$3 \mathrm{~g} / 100 \mathrm{~g}$ fasulye proteini izolatı içeren kek } \\
\hline Kabuk & $17,44 \pm 0,47^{\mathrm{c}}$ & $2,70 \pm 0,29^{c}$ & $3,24 \pm 0,14^{\mathrm{c}}$ & $14,46^{\mathrm{a}}$ & $31,54^{\mathrm{b}}$ \\
\hline İç & $14,39 \pm 0,65^{\mathrm{e}}$ & $7,42 \pm 0,15^{f}$ & $9,98 \pm 0,34^{\mathrm{d}}$ & $6,32^{\mathrm{c}}$ & $145,52^{\mathrm{c}}$ \\
\hline \multicolumn{6}{|c|}{$5 \mathrm{~g} / 100 \mathrm{~g}$ fasulye proteini izolatı içeren kek } \\
\hline Kabuk & $15,87 \pm 1,19^{\mathrm{c}}$ & $4,02 \pm 0,14^{\mathrm{b}}$ & $5,43 \pm 0,22^{b}$ & $14,45^{\mathrm{a}}$ & $60,18^{\mathrm{a}}$ \\
\hline İç & $18,11 \pm 0,38^{\mathrm{f}}$ & $4,50 \pm 0,12^{\mathrm{g}}$ & $5,80 \pm 0,06^{\mathrm{e}}$ & $7,40^{\mathrm{c}}$ & $56,18^{\mathrm{e}}$ \\
\hline
\end{tabular}

${ }^{1}$ Sonuçlar üç ölçümün ortalaması \pm standart sapma şeklinde rapor edilmiştir. Aynı sütun içerisinde (kabuk ve iç olarak iki grup halinde değerlendirilmiş) farklı harflerle gösterilen değerler birbirlerinden istatistiksel olarak önemli düzeyde farklıdır $(p<0,05)$.

Kontrol numunesi ile farklı oranlarda izolat içeren kek numunelerinin arasındaki renk farkı $\left(\Delta \mathrm{E}^{*}\right)$ formülasyonda kullanılan fasulye proteini izolatı oranından etkilenmiştir. Kontrol numunesi ile diğer numuneler arasındaki $\Delta \mathrm{E}^{*}$ değeri 3 ve üzerinde ise renk farkının insan gözü ile algılanabilecek düzeyde olduğu bildirilmiştir (Baixauli ve ark., 2008). Bu bağlamda çalışmamızda fasulye proteini izolatı içeren numunelerdeki renk fark1 gözle ayırt edilebilecek düzeydedir. Özellikle kullanılan izolat oranı arttıkça hem kek kabuk rengi hem de iç rengi için bu farkın da arttığı görülmüştür $(p<0,05)$. İzolat içeren kek numunelerinde izolat oranı arttıkça kabukta esmerleşme indeksinin de arttığı görülmüştür $(p<0,05)$. Benzer sonuçlar fasulye, bezelye ve amarant proteini izolatı içeren kek numuneleri için de rapor edilmiş ve bunun nedeninin, artan protein oranı ile e-ISSN: 2148-2683 birlikte Maillard reaksiyonuna girebilecek amino asit oranının da artması olabileceği ortaya konmuştur (Shevkani \& Singh, 2014).

Kek numunelerinin tekstür analizi sonuçları Tablo 7'de gösterilmiştir. Fasulye protein izolatı içeren kek numunelerinin sertlik değerinin kontrol numunesine göre düşük olduğu gözlenmiştir $(p<0,05)$. Kek numunelerin nem içeriği ile sertlik değerleri arasında pozitif korelasyon olduğu görülmüştür $(p<0,05)$. Nem içeriği yüksek olan kontrol numunesinin sertlik değeri, fasulye proteini izolatı içeren numunelerin sertlik değerinden önemli düzeyde yüksek bulunmuştur $(p<0,05)$. Ürünün nem içeriği formülasyonda kullanılan proteinlerin su tutma kapasitesinden etkilenmektedir. Formülasyonda kullanılan izolat oranı arttıkça ürünün nem içeriğinin ve sertlik değerinin de 
arttığı görülmüştür. Buna karşılık, nohut proteini izolatı (Shaabani ve ark., 2018) ve çeşitli baklagil unları (Gularte ve ark., 2011) ilave edilen keklerde baklagil proteini veya ununun miktarı arttıkça sertlik değerinin de arttığı bildirilmiştir. Kohezyon kapasitesi ve esnekliğin, ürün formülasyonunda bulunan proteinlerin geliştirdiği elastik ağ yapıdan etkilendiği bildirilmiştir (Moore ve ark., 2004; Wilderjans ve ark., 2008). Ürünün ağız hissi ve çiğnenebilirliği ile ilişkilendirilen kohezyon kapasitesinin fasulye proteini izolatı içeren kek numunelerinde kontrol numunesine göre düşük olduğu görülmüştür $(p<0,05)$. Genel olarak ürünün tazelik hissi ile ilişkilendirilen esneklik değerlerinin ise fasulye protein izolatı oranından etkilendiği; 3 $\mathrm{g} / 100 \mathrm{~g}$ oranında izolat içeren numunenin esneklik değerinin kontrol numunesi ile benzer olduğu bulunmuştur. İzolat içeren kek numunelerinin çiğnenebilirlik ve katılık değerlerinin ise kontrole göre düşük olduğu görülmüştür $(p<0,05)$.

Tablo 7. Kek Numunelerinin Tekstür Özellikleri ${ }^{I}$

\begin{tabular}{|c|c|c|c|c|c|}
\hline & $\begin{array}{l}\text { Sertlik } \\
\text { (gf) }\end{array}$ & $\begin{array}{l}\text { Kohezyon } \\
\text { Kapasitesi }\end{array}$ & $\begin{array}{l}\text { Esneklik } \\
(\mathbf{m m})\end{array}$ & $\begin{array}{c}\text { Çiğnenebilirlik } \\
\text { (Nmm) }\end{array}$ & $\begin{array}{c}\text { Katılık } \\
(\mathrm{kgf} / \mathrm{mm})\end{array}$ \\
\hline Kontrol & $375,92 \pm 20,62^{a}$ & $0,40 \pm 0,02^{\mathrm{a}}$ & $4,54 \pm 0,17^{b}$ & $9,89 \pm 0,48^{\mathrm{a}}$ & $0,07 \pm 0,00^{\mathrm{a}}$ \\
\hline $\begin{array}{l}1 \mathrm{~g} / 100 \mathrm{~g} \text { fasulye proteini izolatı } \\
\text { içeren kek }\end{array}$ & $184,65 \pm 17,26^{\mathrm{b}}$ & $0,35 \pm 0,03^{\mathrm{ab}}$ & $2,67 \pm 0,03^{c}$ & $2,44 \pm 0,23^{b}$ & $0,04 \pm 0,00^{\mathrm{b}}$ \\
\hline $\begin{array}{l}3 \mathrm{~g} / 100 \mathrm{~g} \text { fasulye proteini izolatı } \\
\text { içeren kek }\end{array}$ & $191,38 \pm 7,24^{b}$ & $0,15 \pm 0,01^{\mathrm{c}}$ & $4,52 \pm 0,22^{b}$ & $0,87 \pm 0,03^{c}$ & $0,04 \pm 0,00^{\mathrm{b}}$ \\
\hline $\begin{array}{l}5 \mathrm{~g} / 100 \mathrm{~g} \text { fasulye proteini izolatı } \\
\text { içeren kek }\end{array}$ & $221,57 \pm 5,02^{b}$ & $0,33 \pm 0,02^{\mathrm{b}}$ & $5,52 \pm 0,33^{\mathrm{a}}$ & $0,78 \pm 0,05^{\mathrm{c}}$ & $0,04 \pm 0,02^{b}$ \\
\hline
\end{tabular}

Eğitimsiz panelistler ile gerçekleştirilen kontrole göre farklılık testine göre, fasulye proteini izolatı içeren kek numunelerinin lezzet, renk ve doku gibi duyusal özelliklerinin kontrol numunesinden farklı olduğu saptanmıştır $(p<0,05)$. Panelistler tarafindan algılanan farkta izolat içeren keklerin tekstür özelliklerinin (Tablo 7) ve nem içeriğinin (Tablo 4) kontrolden belirgin ölçüde farklı olmasının etkili olduğu düşünülmektedir. Bu bakımdan fasulye proteini izolatı içeren bitkisel bazlı kek formülasyonlarının iyileştirmeye açık olduğu görülmektedir.

\subsection{Fasulye Proteini İzolatının Bitkisel Bazlı Köfte Numunelerinin Kalite Özelliklerine Etkisi}

Bitkisel bazlı köfte numunelerinin besin öğeleri kompozisyonu Tablo 8'de gösterilmiştir. Kontrol numunesi ile fasulye proteini izolatı içeren numunelerin nem içerikleri benzer bulunmuştur. $\mathrm{Bu}$ bulgu, çalışmada kullanılan fasulye proteini izolatının su tutma kapasitesinin kontrol numunesindeki bezelye proteini konsantresinin su tutma kapasitesine benzer olduğuna işaret etmektedir. Ancak ürün formülasyonları söz konusu olduğunda; fasulye proteini izolatı içeren numunelerin su içeriğinin kontrol numunesinden yüksek olduğu da göz önünde bulundurulmalıdır (Tablo 2). Buna karşılık kontrol numunesinin protein içeriği, $1 \mathrm{~g} / 100 \mathrm{~g}$ ve $3 \mathrm{~g} / 100 \mathrm{~g}$ oranında izolat içeren numunelerin protein içeriğinden yüksek bulunmuştur $(p<0,05)$. Kontrol numunesinin formülasyonunda kullanılan bezelye proteini konsantresinin miktarı, konsantrenin protein içeriği $(66,5$ $\mathrm{g} / 100 \mathrm{~g})$ dikkate alınarak belirlenmiştir. Çalışılan numuneler içerisinde $5 \mathrm{~g} / 100 \mathrm{~g}$ oranında izolat içeren köfte numunesinin protein içeriği kontrol ile benzer bulunmuştur. Buna karşılık izolat içeren köfte numunelerinin yağ içeriği, kontrol numunesinden yüksek bulunmuştur $(p<0,05)$. Bu bulgunun olası nedeni bu çalışmada elde edilen fasulye proteini izolatının yağ tutma kapasitesinin ticari bezelye proteini konsantresinden yüksek olabileceğidir.

Tablo 8. Bitkisel Bazlı Köfte Numunelerinin Besin Öğeleri Kompozisyonu ${ }^{1}$

\begin{tabular}{|c|c|c|c|c|c|}
\hline & $\begin{array}{c}\text { Nem } \\
(\mathrm{g} / \mathbf{1 0 0} \mathrm{g})\end{array}$ & $\begin{array}{l}\text { Protein } \\
\text { (g/100 g) }\end{array}$ & $\begin{array}{c}\text { Yağ } \\
(\mathrm{g} / \mathbf{1 0 0} \mathrm{g})\end{array}$ & $\begin{array}{c}\text { Karbonhidrat }^{2} \\
(\mathrm{~g} / \mathbf{1 0 0} \mathrm{g})\end{array}$ & $\begin{array}{c}\text { Kül } \\
(\mathrm{g} / 100 \mathrm{~g})\end{array}$ \\
\hline Kontrol & $38,7 \pm 1,3^{\mathrm{a}}$ & $8,5 \pm 0,2^{\mathrm{a}}$ & $17,1 \pm 0,3^{\mathrm{b}}$ & 33,3 & $2,4 \pm 0,2^{\mathrm{b}}$ \\
\hline $1 \mathrm{~g} / 100 \mathrm{~g}$ fasulye proteini izolatı içeren köfte & $40,4 \pm 3,1^{\mathrm{a}}$ & $6,6 \pm 0,3^{\mathrm{b}}$ & $19,6 \pm 0,1^{\mathrm{a}}$ & 30,6 & $2,8 \pm 0,1^{\mathrm{a}}$ \\
\hline $3 \mathrm{~g} / 100 \mathrm{~g}$ fasulye proteini izolatı içeren köfte & $39,5 \pm 2,7^{\mathrm{a}}$ & $7,2 \pm 0,3^{\mathrm{b}}$ & $19,6 \pm 0,1^{\mathrm{a}}$ & 31,0 & $2,7 \pm 0,1^{\mathrm{a}}$ \\
\hline $5 \mathrm{~g} / 100 \mathrm{~g}$ fasulye proteini izolatı içeren köfte & $43,5 \pm 0,3^{\mathrm{a}}$ & $7,9 \pm 0,1^{\mathrm{a}}$ & $19,6 \pm 0,1^{\mathrm{a}}$ & 26,3 & $2,7 \pm 0,1^{a b}$ \\
\hline
\end{tabular}

Bitkisel bazlı köfte numunelerinin pişme ile ilgili fiziksel özellikleri Tablo 9'da gösterilmiştir. En yüksek verim $(\sim \% 94,6)$ ve en düşük pişme kaybı $(\sim \% 5,4)$ gözlenen numunelerin kontrol ve $5 \mathrm{~g} / 100 \mathrm{~g}$ fasulye proteini izolatı içeren köfte numunesi olduğu görülmüştür. $\mathrm{Bu}$ numunelerin aynı zamanda en yüksek oranda protein içeren numuneler (Tablo 8) olduğu dikkat çekmektedir. Serdaroğlu ve ark. (2005) tarafından yapılan çalışmada çeşitli baklagil unlarının köfte formülasyonunda kullanımının ürünün fiziksel ve pişme özelliklerine etkisi incelenmiştir. Çalışmada börülce, nohut ve mercimek unları ile yapılan ürünlerin köfte 
verimi \%88,6-93,2 arasında bulunmuştur (Serdaroğlu ve ark., 2005). Bu değerler ile çalışmamızda elde edilen değerlerin benzerlik gösterdiği görülmüştür. Kontrol numunesi ile karşılaştırıldığında $1 \mathrm{~g} / 100 \mathrm{~g}$ ve $5 \mathrm{~g} / 100 \mathrm{~g}$ oranında fasulye proteini izolatı içeren numunelerin nem tutma kapasitesinin kontrol örneğinden yüksek olduğu görülmüştür $(p<0,05)$.

Tablo 9. Bitkisel Bazlı Köfte Numunelerinin Pişme ile İlgili Fiziksel Özellikleri ${ }^{l}$

\begin{tabular}{lccc}
\hline & $\begin{array}{c}\text { Köfte Verimi } \\
(\boldsymbol{\%})\end{array}$ & $\begin{array}{c}\text { Pişme Kaybı } \\
(\boldsymbol{\%})\end{array}$ & $\begin{array}{c}\text { Nem Tutma } \\
(\boldsymbol{\%})\end{array}$ \\
\hline Kontrol & $94,8 \pm 0,1^{\mathrm{a}}$ & $5,2 \pm 0,1^{\mathrm{c}}$ & $36,7 \pm 0,0^{\mathrm{c}}$ \\
$1 \mathrm{~g} / 100 \mathrm{~g}$ fasulye proteini izolatı içeren köfte & $93,6 \pm 0,0^{\mathrm{b}}$ & $6,4 \pm 0,0^{\mathrm{b}}$ & $40,7 \pm 0,0^{\mathrm{a}}$ \\
$3 \mathrm{~g} / 100 \mathrm{~g}$ fasulye proteini izolatı içeren köfte & $92,9 \pm 0,1^{\mathrm{b}}$ & $7,2 \pm 0,1^{\mathrm{a}}$ & $36,7 \pm 0,0^{\mathrm{c}}$ \\
$5 \mathrm{~g} / 100$ g fasulye proteini izolatı içeren köfte & $94,4 \pm 0,3^{\mathrm{a}}$ & $5,6 \pm 0,3^{\mathrm{c}}$ & $38,1 \pm 0,1^{\mathrm{b}}$ \\
\hline${ }^{1}$ Sonuçlar üç ölçümün ortalaması \pm standart sapma şeklinde rapor edilmiştir. Aynı sütun içerisinde farklı harflerle gösterilen \\
değerler birbirlerinden istatistiksel olarak önemli düzeyde farklıdır $(p<0,05)$.
\end{tabular}

Bitkisel bazlı köfte numunelerinin kabuk ve içlerine ait renk parametreleri Tablo 10'da gösterilmiştir. Et ürünlerinde renk özellikleri tüketici beğenisini kazanma ve kabul edilebilirlik gibi faktörler üzerinde önem taşımaktadır. Formülasyonda kullanılan fasulye proteini izolatı oranı arttıkça köfte kabuğunda $\mathrm{L}^{*}$ değerlerinin $\operatorname{arttığ~} 1(p<0,05)$; dolayısıyla kabuk renginin açıldığ1 ve kontrolden farklılaştı̆ğ görülmüştür. İzolat içeren numunelerin yağ içeriğinin kontrol numunesine göre önemli ölçüde yüksek olması ve ürün yüzeyinin daha parlak olarak algılanmasına neden olması da bu bulgu için olası bir etkendir (Tablo 8). Yine izolat oranı arttıkça kabukta $a^{*}$ ve $b^{*}$ değerlerinin arttığ1; yani renkte kırmızılığa ve sarılığa doğru bir eğilim olduğu gözlemlenmiştir.
Literatürde baklagil proteinleri kullanılan ürünlerde gözlemlenen renk farkının, ekstraksiyon işlemi sırasında proteine bağlı fenolik bileşiklerin varlığı ve pişirme sırasında ortaya çıkan Maillard reaksiyonlarından kaynaklanabileceği belirtilmiştir (Hera ve ark., 2012; Jarpa-Parra ve ark., 2017). Çalışmamızda kontrol numunesi ile farklı oranlarda izolat içeren köfte numunelerinin arasındaki renk farkı $\left(\Delta \mathrm{E}^{*}\right)$ formülasyonda kullanılan fasulye proteini izolatı oranından etkilenmiştir. İzolat içeren numunelerdeki renk farkı gözle ayırt edilebilecek düzeydedir. Köfte formülasyonunda kullanılan izolat oranı arttıkça hem ürün kabuğu hem de içi için bu renk farkının arttığı görülmüştür $(p<0,05)$.

Tablo 10. Bitkisel Bazlı Köfte Numunelerinin Renk Parametreleri ${ }^{I}$

\begin{tabular}{|c|c|c|c|c|}
\hline & $L^{*}$ & $a^{*}$ & $b^{*}$ & $\Delta E^{*}$ \\
\hline \multicolumn{5}{|l|}{ Kontrol } \\
\hline Kabuk & $34,73 \pm 1,42^{\mathrm{b}}$ & $11,40 \pm 0,24^{\mathrm{c}}$ & $16,43 \pm 0,80^{\mathrm{b}}$ & - \\
\hline İç & $46,23 \pm 0,13^{c}$ & $9,60 \pm 0,21^{\mathrm{f}}$ & $29,23 \pm 0,93^{c}$ & - \\
\hline \multicolumn{5}{|c|}{$1 \mathrm{~g} / 100 \mathrm{~g}$ fasulye proteini izolatı içeren köfte } \\
\hline Kabuk & $37,54 \pm 0,17^{\mathrm{a}}$ & $10,37 \pm 0,17^{\mathrm{c}}$ & $18,27 \pm 0,66^{\mathrm{b}}$ & $3,91^{\mathrm{c}}$ \\
\hline İç & $41,40 \pm 2,35^{\mathrm{d}}$ & $11,41 \pm 0,75^{\mathrm{e}}$ & $21,56 \pm 1,28^{\mathrm{e}}$ & $9,83^{\mathrm{d}}$ \\
\hline \multicolumn{5}{|c|}{$3 \mathrm{~g} / 100 \mathrm{~g}$ fasulye proteini izolatı içeren köfte } \\
\hline Kabuk & $38,35 \pm 0,99^{\mathrm{a}}$ & $13,85 \pm 0,62^{b}$ & $22,24 \pm 0,63^{\mathrm{a}}$ & $7,29^{b}$ \\
\hline İç & $42,03 \pm 1,99^{c d}$ & $10,68 \pm 0,16^{\mathrm{de}}$ & $19,25 \pm 0,28^{\mathrm{e}}$ & $11,49^{\mathrm{d}}$ \\
\hline \multicolumn{5}{|c|}{$5 \mathrm{~g} / 100 \mathrm{~g}$ fasulye proteini izolatı içeren köfte } \\
\hline Kabuk & $38,68 \pm 0,82^{\mathrm{a}}$ & $16,53 \pm 0,50^{\mathrm{a}}$ & $24,24 \pm 1,00^{\mathrm{a}}$ & $10,17^{\mathrm{a}}$ \\
\hline İç & $46,58 \pm 1,06^{\mathrm{c}}$ & $15,15 \pm 0,67^{\mathrm{d}}$ & $25,51 \pm 0,94^{\mathrm{d}}$ & $6,98^{e}$ \\
\hline
\end{tabular}

Bitkisel bazlı köfte numunelerinin tekstür analizi sonuçları Tablo 11'de gösterilmiştir. Fasulye proteini izolatı içeren köfte numunelerinin sertlik ve kohezyon kapasitesi değerlerinin kontrole göre düşük olduğu görülmüştür $(p<0,05)$. Buna karşılık, $3 \mathrm{~g} / 100 \mathrm{~g}$ ve $5 \mathrm{~g} / 100 \mathrm{~g}$ oranında izolat içeren numunelerin esneklik ve çiğnenebilirlik değerleri kontrolden yüksek bulunmuştur $(p<0,05)$. Bu numunelerde fasulye proteini izolatı ilavesi, daha yumuşak, esnek ve çiğnenebilir bir yapı oluşmasını sağlamıştır. Esneklik ve kohezyon kapasitesi gibi parametrelerin formülasyonda bulunan proteinlerin geliștirdiği elastik ağdan etkilendiği bildirilmiştir (Moore ve ark., 2004; Wilderjans ve ark., 2008). Çiğnenebilirlik ve katılık değerlerinde formülasyondaki izolat oranına bağlı belirgin bir trend gözlemlenmemiştir. Son olarak, eğitimsiz panelistler ile gerçekleştirilen kontrole göre farklılık testine göre, $3 \mathrm{~g} / 100 \mathrm{~g}$ ve $5 \mathrm{~g} / 100 \mathrm{~g}$ oranında fasulye proteini izolatı içeren köfte numunelerinin duyusal özelliklerinin kontrol numunesine benzer olduğu saptanmıştır $(p>0,05)$.

Tablo 11. Bitkisel Bazlı Köfte Numunelerinin Tekstür Özellikleri ${ }^{1}$

\begin{tabular}{ccccc}
$\begin{array}{c}\text { Sertlik } \\
(\mathrm{gf})\end{array}$ & $\begin{array}{c}\text { Kohezyon } \\
\text { Kapasitesi }\end{array}$ & $\begin{array}{c}\text { Esneklik } \\
(\mathbf{m m})\end{array}$ & $\begin{array}{c}\text { Çiğnenebilirlik } \\
(\mathrm{Nmm})\end{array}$ & $\begin{array}{c}\text { Katıllk } \\
(\mathbf{k g f} / \mathbf{m m})\end{array}$ \\
\hline
\end{tabular}




\begin{tabular}{lccccc}
\hline Kontrol & $375,92 \pm 20,62^{\mathrm{a}}$ & $0,40 \pm 0,01^{\mathrm{a}}$ & $1,86 \pm 0,05^{\mathrm{b}}$ & $1,08 \pm 0,01^{\mathrm{d}}$ & $0,56 \pm 0,03^{\mathrm{c}}$ \\
$1 \mathrm{~g} / 100 \mathrm{~g}$ fasulye proteini izolatı içeren köfte & $191,38 \pm 7,24^{\mathrm{b}}$ & $0,35 \pm 0,03^{\mathrm{ab}}$ & $1,39 \pm 0,09^{\mathrm{c}}$ & $5,55 \pm 0,04^{\mathrm{b}}$ & $0,76 \pm 0,00^{\mathrm{b}}$ \\
$3 \mathrm{~g} / 100 \mathrm{~g}$ fasulye proteini izolatı içeren köfte & $184,62 \pm 17,25^{\mathrm{b}}$ & $0,15 \pm 0,01^{\mathrm{c}}$ & $2,38 \pm 0,23^{\mathrm{a}}$ & $9,23 \pm 0,22^{\mathrm{a}}$ & $0,43 \pm 0,00^{\mathrm{d}}$ \\
$5 \mathrm{~g} / 100 \mathrm{~g}$ fasulye proteini izolatı içeren köfte & $221,57 \pm 5,02^{\mathrm{b}}$ & $0,33 \pm 0,02^{\mathrm{b}}$ & $2,60 \pm 0,04^{\mathrm{a}}$ & $2,53 \pm 0,17^{\mathrm{c}}$ & $1,07 \pm 0,01^{\mathrm{a}}$ \\
\hline
\end{tabular}

${ }^{1}$ Sonuçlar üç ölçümün ortalaması \pm standart sapma şeklinde rapor edilmiştir. Aynı sütun içerisinde farklı harflerle gösterilen değerler birbirlerinden istatistiksel olarak önemli düzeyde farklıdır $(p<0,05)$.

\section{Sonuç}

Fasulye proteini izolatı içeren kek numunelerinin tekstür özelliklerinin kontrol numunesinden farklı olduğu görülmüştür. Duyusal analiz değerlendirmeleri sonucunda fasulye proteini izolatı kekte tüketici tarafından önemli belirgin bir farka neden olmuştur. $\mathrm{Bu}$ bağlamda fasulye proteini izolatı içeren bitkisel bazlı kek formülasyonları ürünün nem içeriği, rengi, tekstür özellikleri ve duyusal özellikler açısından iyileştirmeye ihtiyaç duymaktadır. Öte yandan, bitkisel bazlı köfte numunelerinden 3 $\mathrm{g} / 100 \mathrm{~g}$ ve $5 \mathrm{~g} / 100 \mathrm{~g}$ oranında fasulye proteini izolatı içerenler tekstür özellikleri açısından kabul edilebilir ve duyusal özellikler bakımından da kontrole yakın bulunmuştur. $\mathrm{Bu}$ çalışma sonucu elde edilen bulgular, ülkemize özgü baklagillerin ve bunlardan elde edilen bileşenlerinin bitkisel bazlı firıncılık ve et ürünlerinde protein kaynağı olarak kullanılabileceğini göstermiştir. Çalışmada geliştirilen kek ve köfte formülasyonları, daha yüksek oranda fasulye proteini ilavesi veya farklı baklagil-tahıl proteini kombinasyonları kullanılarak renk, görünüş, tekstür özellikleri ve duyusal özellikler açısından iyileştirilmeye açıktır.

\section{Kaynakça}

Alves, J.S., Rodrigues, A.S., Moro, K.I.B., Boeira, C.P., Londero, P.M.G., \& Rosa, C.S. (2019). Chemical characterization, bioactive compounds, and functional technological properties of flour from two cultivars of landrace common beans (Phaseolus vulgaris L.). International Food Research Journal, 26, 565-572.

AOAC. (1990). Official Methods of Analysis, Association of Official Analytical Chemists, Arlington, VA., USA.

Asgar, M., Fazilah, A., Huda, N., Bhat, R., \& Karim, A. (2010). Nonmeat protein alternatives as meat extenders and meat analogs. Comprehensive Reviews in Food Science and Food Safety, 9, 513-529.

Aydoğan, M., Demiryürek, K., \& İlkay, A.N. (2015). Türkiye'de kuru fasulye üretiminin mevcut durumu ve gelecek dönemler üretiminin tahmin edilmesi. Türk Tarım-Glda Bilim ve Teknoloji Dergisi, 3, 962-968.

Azarpazhooh, E., \& Boye, J.I. (2013). Composition of Processed Dry Beans and Pulses. In M. Siddiq, M.A. Uebersax (Eds.), Dry Beans and Pulses Production, Processing and Nutrition. John Wiley \& Sons, 103-1224.

Baixauli, R., Salvador, A., \& Fiszman, S. (2008). Textural and colour changes during stroage and sensory shelf life of muffins containing resistant starch. European Food Research and Technology, 226, 523-530.

Boye, J., Zare, F., \& Pletch, A. (2010). Pulse proteins: Processing, characterization, functional properties and applications in food and feed. Food Research International, 43, 414-431.

Çulal Kılıç, H., Kök, H., \& Yardımcı, N. (2020). Bean Common Mosaic Virus (BCMV) and Bean Common Necrosis Mosaic Virus (BCMNV) infections in common bean fields in the Lakes Region, Turkey. Avrupa Bilim ve Teknoloji Dergisi, 19, 386-392.
Dizlek, H., \& Altan, Ali. (2013). Pişirme öncesinde hamurun kısa süre bekletilmesinin pandispanya nitelikleri üzerine etkisi. Gıda Dergisi, 38, 31-38.

Ferreira, C.D., Ziegler, V., Lindemann, I.D., Hoffmann, J.F., Vanier, N.L., \& Oliveira, M.D. (2018). Quality of black beans as a function of long-term storage and moldy development: Chemical and functional properties of flour and isolated protein. Food Chemistry, 246, 473-480.

Guadarrama-Lezama, A., Carrillo-Navas, H., Pérez-Alonso, C., Vernon-Carter, E., \& Alvarez-Ramirez, J. (2016). Thermal and rheological properties of sponge cake batters and texture and microstructural characteristics of sponge cake made with native corn starch in partial or total replacement of wheat flour. LWT - Food Science and Technology, 70, 46-54.

Gularte, M.A., Gómez, M., \& Rosell, C.M. (2011). Impact of legume flours on quality and in vitro digestibility of starch and protein from gluten-free cakes. Food and Bioprocess Technology, 5, 3142-3150.

He, Q., Sun, X., He, S., Wang, T., Zhao, J., Yang, L., Wu, Z., \& Sun, H. (2018). PEGylation of black kidney bean (Phaseolus vulgaris L.) protein isolate with potential functironal properties. Colloids and Surfaces B: Biointerfaces, 164, 8997.

Hera, E.D., Ruiz-París, E., Oliete, B., \& Gómez, M. (2012). Studies of the quality of cakes made with wheat-lentil composite flours. LWT - Food Science and Technology, 49, 48-54.

Jarpa-Parra, M., Wong, L., Wismer, W., Temelli, F., Han, J., Huang, W., Eckhart, E., Tian, Z., Shi, K., Sun, T., \& Chen, L. (2017). Quality characteristics of angel food cake and muffin using lentil protein as egg/milk replacer. International Journal of Food Science \& Technology, 52, 1604-1613.

Kumar, M., \& Sharma, B.D. (2004). The storage stability and textural, physico-chemical and sensory quality of low-fat ground pork patties with Carrageenan as fat replacer. International Journal of Food Science and Technology, 39, 31-42.

Lafarga, T., Álvarez, C., Bobo, G., \& Aguiló-Aguayo, I. (2018). Characterization of functional properties of proteins from Ganxet beans (Phaseolus vulgaris L. var. Ganxet) isolated using an ultrasound-assisted methodology. LWT - Food Science and Technology, 98, 106-112.

Lin, M., Tay, S.H., Yang, H., Yang, B., \& Li, H. (2017). Replacement of eggs with soybean protein isolates and polysaccharides to prepare yellow cakes suitable for vegetarians. Food Chemistry, 229, 663-673.

Majzoobi, M., Ghiasi, F., Habibi, M., Hedayati, S., \& Farahnaky, A. (2013). Influence of soy protein 1solate on the quality of batter and sponge cake. Journal of Food Processing and Preservation, 38, 1164-1170.

Meilgaard, M., Civille, G.V., \& Carr, B.T. (2007). Sensory Evaluation Techniques, CRC Press, Taylor \& Francis Group, Boca Raton, 92-100.

Moore, M.M., Schober, T.J., Dockery, P., \& Arendt, E.K. (2004). Textural comparisons of gluten-free and wheat-based doughs, batters, and breads. Cereal Chemistry, 81, 567-575. 
Paraskevopoulou, A., Donsouzi, S., Nikiforidis, C., \& Kiosseoglou, V. (2015). Quality characteristics of eggreduced pound cakes following WPI and emulsifier incorporation. Food Research International, 69, 72-79.

Rui, X., Boye, J.I., Ribereau, S., Simpson, B.K., \& Prasher, S.O. (2011). Comparative study of the composition and thermal properties of protein isolates prepared from nine Phaseolus vulgaris legume varieties. Food Research International, 44, 2497-2504.

Sánchez-Arteaga, H., Urías-Silvas, J., Espinosa-Andrews, H., \& García-Márquez, E. (2014). Effect of chemical composition and thermal properties on the cooking quality of common beans (Phaseolus vulgaris). CyTA - Journal of Food, 13, 385-391.

Sathe, S.K. (2002). Dry bean protein functionality. Critical Reviews in Biotechnology, 22, 175-223.

Serdaroğlu, M., Yıldız-Turp, G., \& Abrodímov, K. (2005). Quality of low-fat meatballs containing legume flours as extenders. Meat Science, 70, 99-105.

Shaabani, S., Yarmand, M.S., Kiani, H., \& Emam-Djomeh, Z. (2018). The effect of chickpea protein isolate in combination with transglutaminase and xanthan on the physical and rheological characteristics of gluten free muffins and batter based on millet flour. LWT - Food Science and Technology, $90,362-372$.
Shevkani, K., \& Singh, N. (2014). Influence of kidney bean, field pea and amaranth protein isolates on the characteristics of starch-based gluten-free muffins. International Journal of Food Science \& Technology, 49, 2237-2244.

Turp, G.Y. (2016). Effects of four different cooking methods on some quality characteristics of low fat Inegol meatball enriched with flaxseed flour. Meat Science, 121, 40-46.

Wani, I.A., Sogi, D.S., Shivhare, U.S., \& Gill, B.S. (2015). Physico-chemical and functional properties of native and hydrolyzed kidney bean (Phaseolus vulgaris L.) protein isolates. Food Research International, 76, 11-18.

Wilderjans, E., Pareyt, B., Goesaert, H., Brijs, K., \& Delcour, J.A. (2008). The role of gluten in a pound cake system: A model approach based on gluten-starch blends. Food Chemistry, 110, 909-915.

Yeken, M.Z., Kantar, F., Çanc1, H., Özer, G., \& Çiftçi, V. (2018). Breeding of dry bean cultivars using Phaseolus vulgaris landraces in Turkey. Uluslararası Tarım ve Yaban Hayatı Bilimleri Dergisi, 4, 45-54.

Yolci, M.S. (2020). Erciş (Van) ekolojik koşullarinda bazi fasulye (Phaseolus vulgaris L.) çeşitlerinin verim ve verim unsurlarının belirlenmesi. Avrupa Bilim ve Teknoloji Dergisi, $18,562-567$. 